group 2 had $\mathrm{HbA} 1 \mathrm{c}>7.0 \%(n=44)$. Long-term monitoring of blood glucose levels was conducted with using the CGMS system during 6 days. Maximum blood glucose level, minimum blood glucose level and the difference of maximum and minimum blood glucose levels were accounted. The mathematical equation was obtained by using the simple linear regression analysis. This mathematical equation shows relationship between the level of albuminuria and the difference between maximum and minimum blood glucose levels. It can be used to predict the progression of diabetic nephropathy in patients with type 1 diabetes. We suggested the method for prognosticating the development and progression of diabetic microangiopathy (on an example of diabetic nephropathy) in patients with diabetes mellitus type 1 that does not require special software. This calculation may be performed using self-monitoring of blood glucose in clinical practice.

DOI:10.31718/2077-1096.18.4.47

УДК 616.831.94-005.1-036-07:616

Полковнікова К. Ю.

ОСОБЛИВОСТІ КЛІНІЧНОГО ПЕРЕБІГУ СУБАРАХНОЇДАЛЬНОГО КРОВОВИЛИВУ НЕТРАВМАТИЧНОГО ГЕНЕЗУ У ГОСТРОМУ ПЕРІОДІ ЗАХВОРЮВАННЯ

\author{
ДУ «Запорізька медична академія післядипломної освіти МОЗ України»
}

Мета дослідження: вивчити клініко-статистичну характеристику, особливості перебігу захворювання, динаміку результатів неврологічних шкал і структуру ускладнень у стаціонарних хворих, госпіталізованих з приводу субарахноїдального крововиливу нетравматичної етіології. Обстежено 87 пацієнтів із субарахноїдальним крововиливом, з них 38 (43,68\%) - з ізольованим, 14 (16,09\%) - 3 субарахноїдально-паренхіматозним, 29 (33,33\%) - з субарахноїдально-вентрикулярним, 6 (6,9\%) - 3 субарахноїдально-паренхіматозно-вентрикулярним крововиливом, загальна кількість змішаних крововиливів складала 56,32\%. У рутинне клінічне обстеження були додатково включені шкала C.S. Ogilvy et B.S. Carter ma шкала GOSE. Більшість хворих даної вибірки мали найлегший ступінь тяжкості субарахноїдального крововиливу згідно класифрікації Всесвітньої організації нейрохірургів - 33 пацієнта (37,93\%), що відповідає 15 балам за шкалою ком Глазго та відсутності рухового та мовного дефрiциту. Друга ступінь тяжкості діагностована у 37 чоловік (42,53\%), це 13-14 балів за шкалою ком Глазго та відсутність рухового і мовного дефріциту. Наступна невелика когорта пацієнтів відносилася до 3 ступеню тяжкості - 14 хворих (16,09\%), вони мали 13-14 балів за шкалою ком Глазго та певного ступеню вираженості руховий і / або мовний дефріцит. Дві людини були віднесені до 4 ступеню тяжкості (2,30\%) із 7-12 балами за шкалою ком Глазго та наявністю / відсутністю рухового і / або мовного дефрiциту. Один хворий $(1,15 \%)$ належав до категорії крайного 5 ступеню тяжкості із 3-6 балами за шкалою ком Глазго та наявністю / відсутністю рухового і / або мовного дефіциту. Відсоток вірогідності прогнозу субарахноїдального крововиливу 78-80\% успішного результату згідно узагальнюючої класифікаційної шкали для оцінки прогнозу результату субарахноїдального крововиливу (C.S. Ogilvy et B.S. Carter) мали 76 хворих із балами від 0 до 2 (87,36\%). Tpu бали та 65-67\%, менш успішний результат продемонстрували 10 хворих $(11,49 \%)$. У одного хворого $(1,15 \%)$ нараховано $25 \%$, несприятливий результат та сумарні 4 бали. Виявлені наступні фактори ризику розвитку субарахноїдального крововиливу: наявність в сімейному анамнезі даного захворювання у родичів; наявність в анамнезі шкідливих звичок: паління; зловживання алкоголем; наявність в анамнезі гіпертонічної хвороби, атеросклерозу та гіперхолестеринемії. Із супутніх хвороб найбільш широко були представлені такі захворювання, як ішемічна хвороба серця, виразкова хвороба шлунка, цукровий діабет.

Ключові слова: субарахноїдальний крововилив, Шкала Всесвітньої федерації нейрохірургів (WFNS), шкала Ханта-Хесса, шкала Fisher, шкала C.S. Ogilvy et B.S. Carter, шкала GOSE.

Робота є фррагментом НДР кафедри нервових хвороб ДЗ «Запорізька медична академія післядипломної освіти МОз України»: «Комплексна діагностика та алгоритми прогнозування перебігу субарахноїдальних кро-вовиливів у хворих різних вікових груп», № держ. реєстрації $0115 \cup 000657$.

В Україні щороку відбувається до 5 тисяч аневризматичних крововиливів при середньому показнику захворюваності 12 випадків / 100 тисяч чоловік на рік на 42 мільйони населення $[1,2,3]$.

Субарахноїдальний крововилив (САК) становить лише 5\% всіх випадків інсульту [4], але має досить високі показники смертності та необоротну втрату працездатності. Ретроспективне когортне дослідження у двох великих норвезьких популяціях за період з 1984 по 2007 рр. свідчило

Том 18, Випуск 4 (64)

про те, що смертність за 30 днів становила $36 \%$ [5]. Загальнонаціональне данське дослідження показало, що аналогічний 30-денний показник смертності становив 38\% [6]. Тенденції та детермінанти багатонаціонального моніторингу Всесвітньої організації охорони здоров'я в дослідженні серцево-судинних захворювань (дослідження інсульту WHO MONICA), велике спостереження за 11-ма популяціями в Європі та Китаї повідомили про те, що смертність протягом 30 днів становить $42 \%$. Огляд даних показників 
смертності в Швеції та основної причини смерті з 1987 по 2002 рр. виявив у 18443 пацієнтів із САК на 28 день смертність 31,7\% [7]. Ще одне дослідження в Австралії та Новій Зеландії встановило 28-денний показник смертності на рівні 39\% [8]. Ризик постійної втрати працездатності $€$ дуже високим серед тих пацієнтів, що вижили, а рівень захворюваності становить приблизно $50 \%$ [9].

Частота появи нових випадків САК у Сполучених Штатах становить близько 30000 чоловік на рік або 10/100 000 чоловік / рік [10]. Розрив аневризми головного мозку становить від 75 до 85\% випадків САК для нетравматичного варіанту [11]. В одному систематичному огляді встановлена поширеність САК від 3,6\% до 6,0\% на основі аутопсії та ангіографрічних досліджень [12]. Більшість аневризм були невеликими (<1см) 3 ризиком розриву $0,7 \%$. Нещодавній систематичний огляд озвучив показник поширеності САК $3,2 \%$.

Важливими факторами ризику появи аневризми головного мозку $є$ гіпертонія, куріння, хронічне вживання алкоголю [13], сімейний анамнез наявності внутрішньочерепних аневризм у родичів першого ступеню [14], а також жіноча стать $[15,16]$.

Хоча раннє хірургічне або ендоваскулярне лікування розривів аневризми та активне післяопераційне лікування покращує загальний результат відновлення пацієнтів, САК залишається основною причиною фізичних, психологічних та фінансових збитків у розвинених країнах, а також у країнах, що розвиваються. Таким чином, САК залишається всесвітньою провідною причиною неврологічної смерті та інвалідності, менше половини пацієнтів, що вижили після САК, повертаються до повноцінної функціональної фрізич- ної незалежності, що потребує пошуку нових шляхів удосконалення діагностики та попередження розвитку ускладнень перебігу цього грізного захворювання з метою зменшення показників смертності та інвалідизації.

\section{Мета дослідження}

Вивчити клініко-статистичну характеристику, особливості перебігу захворювання, динаміку результатів неврологічних шкал і структуру ускладнень у стаціонарних хворих, госпіталізованих з приводу САК нетравматичної етіології.

\section{Матеріали та методи дослідження}

Обстежено 87 пацієнтів із САК, з них 38 $(43,68 \%)$ з ізольованим САК, $14(16,09 \%)$ - 3 субарахноїдально-паренхіматозним, 29 (33,33\%) - $з$ субарахноїдально-вентрикулярним, 6 (6,9\%) - 3 субарахноїдально-паренхіматозновентрикулярним крововиливом, загальна кількість змішаних крововиливів складала 56,32\%.

САК внаслідок розриву мішотчатої аневризми (МА) підтверджено ангіографічним методом у 63 пацієнтів $(72,41 \%)$, у 5 з них стався повторний крововилив із МА, що розірвалася. У решти випадків $(27,59 \%)$ наявність МА або артеріовенозної мальформації інструментально не верифікувалась, проте ангіографічне обстеження цим пацієнтам проведено одноразово.

Нами використовувалися уніфіковані критерії оцінки вогнищевих неврологічних порушень. Вивчався ступінь виразності менінгеальних симптомів (згідно класичних рекомендацій).

Використовували узагальнюючу класифікаційну шкалу для оцінки прогнозу результату САК C.S. Ogilvy et B.S. Carter і таблицю оцінки прогнозів САК [17] (табл. 1, 2).

Таблиия 1 Узагальнююча класифікаційна шкала для оцінки прогнозу результату CAK C.S. Ogilvy et B.S. Carter

\begin{tabular}{|l|c|}
\hline \multicolumn{1}{|c|}{ Критерії } & \multicolumn{1}{|c|}{ Бали } \\
\hline Вік більш 50 років & 1 \\
\hline Згідно шкали Ханта-Хеса 4 чи 5 балів & 1 \\
\hline Згідно шкали Фішера 3 чи 4 бали & 1 \\
\hline Мозкова аневризма більше 10 мм & 1 \\
\hline Мозкова аневризма вертебробазилярного басейну розміром 25 мм & 1 \\
\hline
\end{tabular}

Таблиия 2

Оцінка прогнозу результату САК

\begin{tabular}{|c|c|}
\hline Сума балів згідно критеріїв & Відсоток вірогідності прогнозу САК \\
\hline $0-2$ & $78-80 \%$, успішний результат \\
\hline 3 & $65-67 \%$, менш успішний результат \\
\hline $4-5$ & $25 \%$, несприятливий результат \\
\hline
\end{tabular}

Таблиця 3

\begin{tabular}{|c|c|c|}
\hline Стадія & GCS score, шкала коми Глазго & Руховий дефіцит/афазія \\
\hline I & 15 & $\mathrm{Hi}$ \\
\hline II & $14-13$ & $\mathrm{Hi}$ \\
\hline III & $14-13$ & Так \\
\hline IV & $12-7$ & Так чи ні \\
\hline V & $6-3$ & Так чи ні \\
\hline
\end{tabular}


Крім того, клінічний моніторинг проводився із урахуванням тяжкості стану хворих при надходженні, оцінювали за класифікацією Hunt i Hess [18], що характеризує наявність і вираженість менінгеальних знаків, фокального неврологічного дефіциту, рівня зміни свідомості.

Шкала Всесвітньої федерації нейрохірургів (WFNS) розроблена на основі критичного аналізу прогностичної цінності параметрів, використовуваних в шкалі Ханта-Хеса, крім того, в неї ввели оцінку рівня свідомості за шкалою коми Глазго (табл. 3).

Суттєвим доповненням для вирішення поставлених завдань була оцінка структурних характеристик головного мозку і лікворовмісних просторів, що проводилося за допомогою рентгенівської комп'ютерної томографії (рентгенівський комп'ютерний томографр «Toshiba» Asteon Super 4).

Оцінка даних проводилася за єдиною методикою [19]. Методологія оцінки томограм полягала у «визначенні рівня зрізу» мозку на підставі ідентифікації анатомічних утворень відповідно заданим площинам дослідження i виявлення томографічних феноменів, що дають інформацію про характер патологічних змін головного мозку. До числа таких феноменів відносяться зміна щільності речовини головного мозку (вогнищева та дифузна), розмірів і конфігурації лікворовмісних просторів мозку, наявність і ступінь поширеності місцевого і загального набряку головного мозку. Аналіз томографічної картини включав в себе як загальну візуальну оцінку, так і визначення кількісних показників. Враховувалися розміри, кількість і локалізація вогнищ зміненої щільності, що виявляються на послідовних зрізах в динаміці, а також наявність дифузної зміни щільності білої речовини в перивентрикулярних зонах і семіовальних центрах. Для вимірювання щільності речовини головного мозку використовували умовні одиниці щільності за шкалою Hounsfield [20].

Розповсюдження крові по субарахноїдальним просторам було оцінене згідно наступних критеріїв [21]: ступінь 0 - відсутність візуалізації крововиливу; ступінь 1 - наявність крові в параселярній області; ступінь 2 - кров у параселярній області та цистернах стовбура; ступінь 3 - кров у параселярній області, цистернах стовбура і латеральній борозні; ступінь 4 - кров у всіх базальних цистернах і латеральній борозні.

Для характеристики масивності крововиливу застосовувалася модіфікована шкала Fisher [22] - система оцінки тяжкості крововиливу за даними комп'ютерної томографії.

0 - Немає САК або внутришньошлуночкового крововиливу (ВШК)

1 Мінімальне або тонке САК без ознак ВШК в будь-якому із бічних шлуночків

2 Мінімальне або тонке САК з ознаками ВШК в обох бічних шлуночках

3 Товсте САК без ознак ВШК в будь-якому з бічних шлуночків
4 Товсте САК з ознаками ВШК в обох бічних шлуночках [23].

Для оцінки клініко-анатомічної форми крововиливу, використовували класифікацію Лебедєва В. В. [24], в якій також враховується наявність або відсутність дислокаційного синдрому.

Пацієнтам проводилася магнітно-резонансна томографія головного мозку із використанням магнітно-резонансного томографру i_Open 0.36T, що використовує постійний магніт із вертикальним магнітним полем напруженістю 0,36 Тесла. Магнітна система томографра i_Open 0.36T створює магнітне поле з найвищою в галузі однорідністю 5ppm (Vrms) в ссрері діаметром 40 см, що забезпечує отримання достовірних даних без спотворень в усій області дослідження. Потужна радіочастотна система з РЧ-підсилювачем потужністю до 6 кВт в поєднанні з потужної градієнтною системою забезпечують оптимальні для MP томографра значення градієнта в межах від 11 до 30 мT/м і швидкістю нарощування від 55 до 120 мТ/м/мс, що дозволяє отримувати радіочастотні імпульси оптимальної форми і дає більшу гнучкість при формуванні необхідних послідовностей.

Для проведення селективного і тотального ангіографічного дослідження використовували ангіографічний комплекс AXIOM Artis MP «Siemens». Кожному хворому проводилось селективне дослідження всіх судинних басейнів через феморальний доступ за методикою Сельдингера. Умови ангіографії були постійні: фокусна відстань 100 см; в якості рентгеноконтрастної речовини використовувався $76 \%$ розчин верографріну, який вводили в загальну сонну артерію в кількості 10 мл. Оцінювалися всі фази кровотоку. Математична обробка графічної інформації здійснювалася з використанням програмного забезпечення ангіографа. У разі нетипової топографії AА дослідження проводилося в режимі ротації для уточнення просторової орієнтації виявленої АА. Ангіографічна характеристика артеріального спазму проводилася з використанням програмного забезпечення ангіографрічної комплексу (при наявності звуження просвіту артерій більше $50 \%$ ) і кількісної методики оцінки діаметра церебральних артерій (визначення співвідношення діаметра вимірюваної ділянки артерії сегменти A1, M1, супраклиноїдна частина ВCA на відстані 0,5 см від розвилки ВСА - до діаметру тієї ж ділянки артерії в нормі) [25].

Статистичний аналіз проводили 3 використанням пакетів прикладних програм «Statistica 6.1» (StatSoft Inc., США, серийный номер RGXR412D674002FWC7), «Microsoft Excel 2013». Для всіх видів аналізу статистично значущими вважали відмінності при р<0,05. При дослідженні частот зустрічі показників проводили за допомогою критерію $X^{2} 3$ аналізом таблиць спряженості. Окремі статистичні процедури і алгоритми реалізовані у вигляді спеціально написаних макросів у відповідних програмах.

Том 18, Випуск 4 (64) 


\section{Результати дослідження}

Розподіл за віком типовий для даного захворювання - більшість хворих перебувало у віці від 30 до 60 років, з переважанням хворих у віці 40-60 років, хворі похилого віку (старше 60 років) - 20,7\% (рис. 1). Середній вік склав 49, 97 років. Чоловіків було 44 , жінок - 43.
Виявлено наступні епідеміологічні дані:

- переважання осіб чоловічої або жіночої статі не виявлено;

- серед пацієнтів обох статей переважали особи раннього зрілого віку: у жінок - 63,2\%, у чоловіків - $50 \%$ (рис. 2 ).

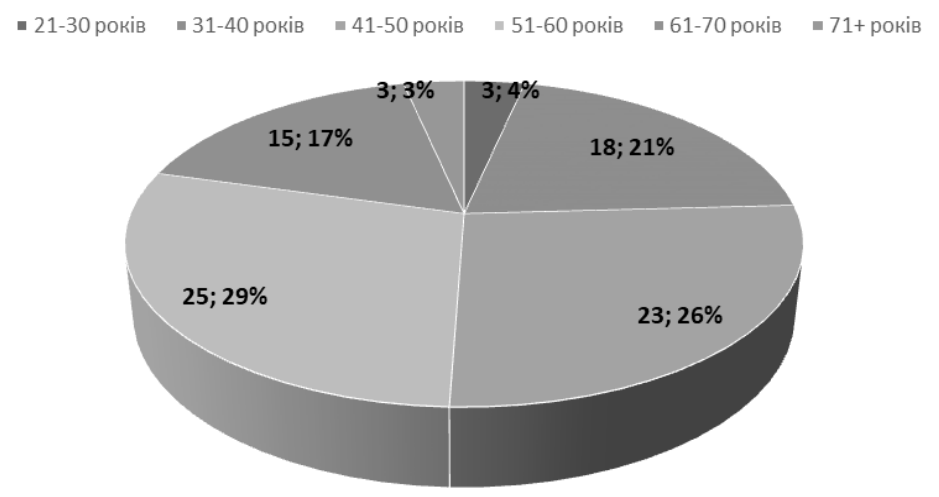

Рuc. 1. Розподіл хворих за віком

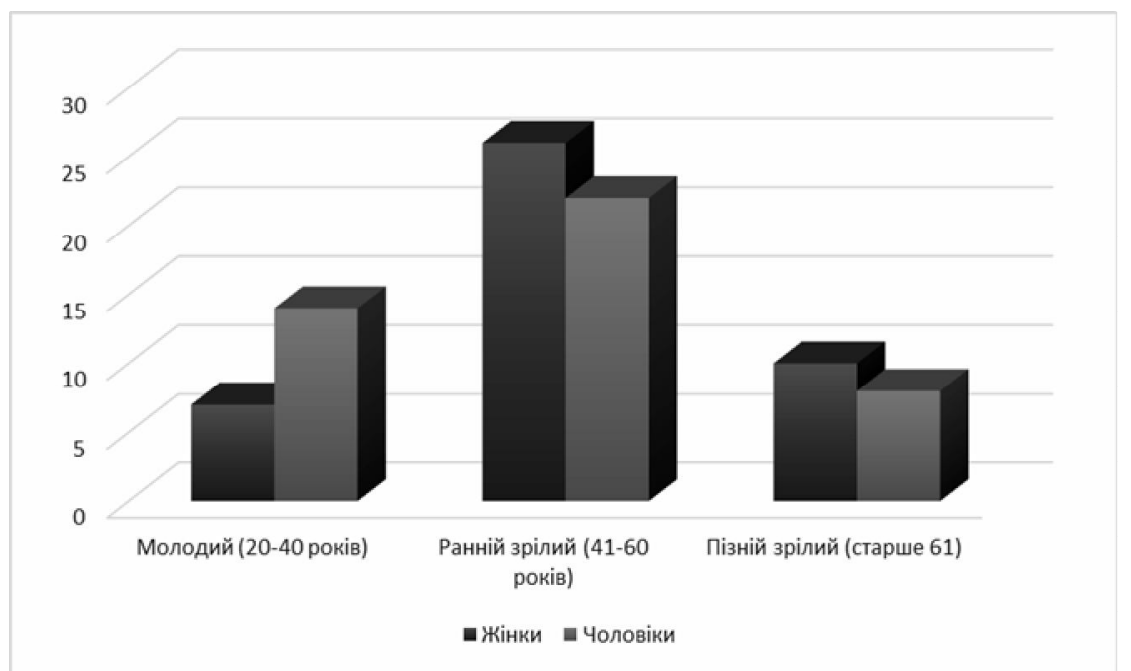

Puc. 2. Частка пацієнтів із САК в різних вікових групах та гендерному співвідношенні

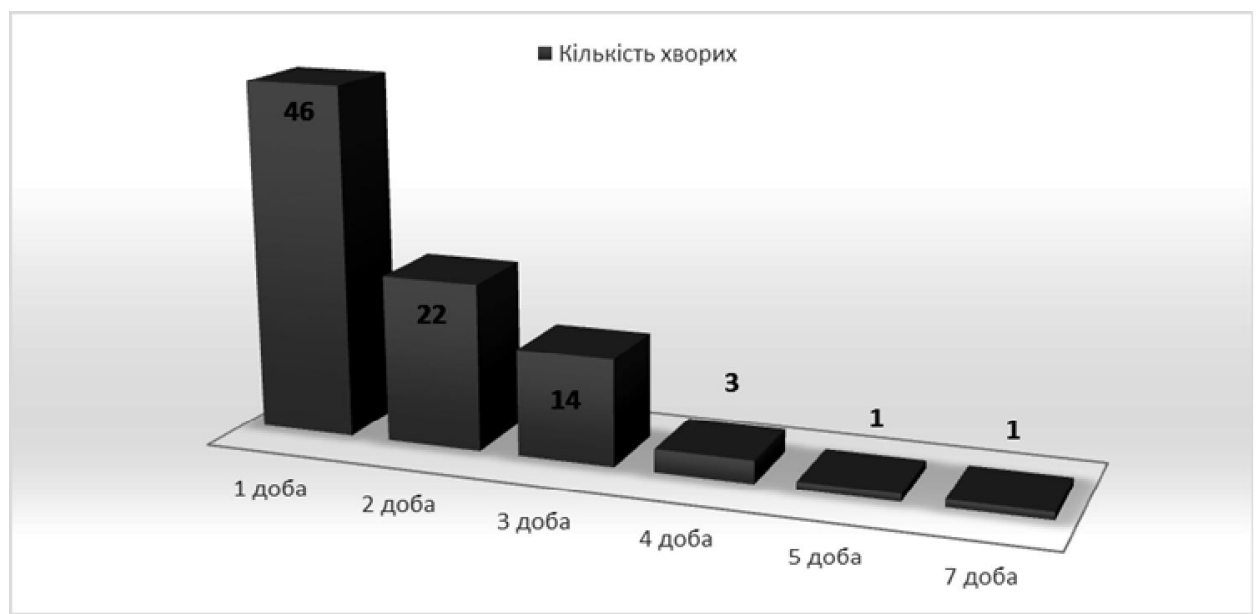

Puc. 3. Розподіл хворих залежно від часу надходження в стаціонар 
Оцінка термінів госпіталізації хворих при САК показала, що надходження більше половини чоловік $(52,87 \%)$. Хворі, що надійшли, відповідно до загальноприйнятих положень, в найбільш сприятливий для хірургічного втручання період, важну більшість (82 пацієнта, 94,25\%). (рис. 3).У більшості хворих з рецидивуючими САК інтервал між останнім і передостаннім крововиливом склав менше 30 діб (5 осіб). У 1 хворого цей інтервал був більше 30 діб. У 3 з них він склав більше 1 року, в тому числі у 2 - більше 10 років. Максимальний термін між САК склав 19 років.

Троє хворих були оперовані з приводу церебральних аневризм за 15, 10 і 7 років до повторного надходження. При повторному надходженні хворих відбулося в першу добу після САК - 46 тобто в перші 3-є діб після САК, складали пере-

було встановлено, що нові крововиливи обумовлені аневризмами іншої локалізації.

Розподіл хворих за локалізацією аневризм представлено в таблиці 4.

Отримані дані свідчили, що найбільш часто виявлялися аневризми передньої мозкової артерії та передньої сполучної артерії ПМА-ПСА $25,29 \%$, внутрішньої сонної артерії $(14,94 \%)$ та середньої мозкової артерії (22,99\%), а найбільш рідко - аневризми вертебро-базилярного басейну $(2,3 \%)$ і периферичні аневризми. Таким чином, частота верифрікації МА ПМА-ПСА та СМА була достовірно частіше, ніж МА інших локалізацій.

Великі і гігантські аневризми діагностовані у 13 хворих (великі - 10 пацієнтів, гігантські - 2-є осіб, фузіформні - у 1 людини), що склало кумулятивно $14,94 \%$.

Таблиця 4 Розподіл за локалізацією аневризм

\begin{tabular}{|c|c|c|}
\hline Локалізація аневризми & $\begin{array}{l}\text { Кількість } \\
\text { хворих }\end{array}$ & $\%$ \\
\hline Не виявлено & 24 & $27,59 \%$ \\
\hline Передня мозкова артерія, передня сполучна артерія, ПМА-ПСА & 22 & $25,29 \%$ \\
\hline Внутрішня сонна артерія, ВСА & 13 & $14,94 \%$ \\
\hline Середня мозкова артерія, СМА & 20 & $22,99 \%$ \\
\hline Основна артерія & 1 & $1,15 \%$ \\
\hline Хребтова артерія & 1 & $1,15 \%$ \\
\hline Сегмент А2 ПМА & 4 & $4,6 \%$ \\
\hline Задня мозкова артерія, ЗМА & 2 & $2,3 \%$ \\
\hline Усього & 87 & $100 \%$ \\
\hline
\end{tabular}

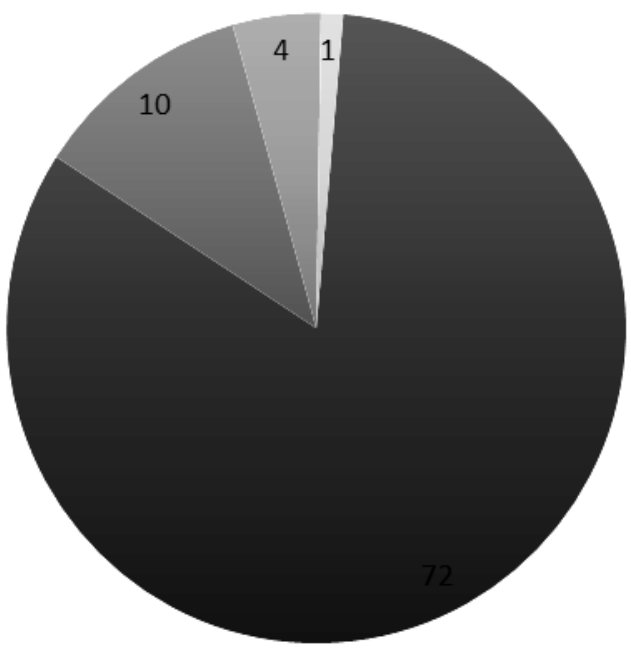

1 аневризма

- 2 аневризми

- 3 аневризми 4 аневризми

Множинні аневризми виявлено у 15 хворих $(17,24 \%)$ (рис. 4).

Таким чином, у 87 хворих було виявлено 108 аневризм.

Різні супутні захворювання зафіксовані у 55 $(63,22 \%)$ пацієнтів. Вони представлені різноманітними органічними і функціональними ураженнями як головного мозку, так інших органів і систем. Найбільшу увагу ми приділяли захворюваності на гіпертонічну хворобу, так як остання, по-

Том 18, Випуск 4 (64)

Рис. 4. Розподіл хворих за кількістю виявлених аневризм перше, вважається якщо не етіологічним, то патогенетичним фактором формування аневризм, а по-друге, призводить до різноманітних патологічних змін судинної системи мозку, що знижує ауторегуляторні можливості останньої i, тим самим, ускладнює перебіг постгеморагічного і післяопераційного періодів.

Артеріальна гіпертонія в анамнезі відзначена у 43 хворих $(49,43 \%)$. Таким чином, із урахуванням переважання серед хворих 3 аневризмами 
осіб старше 40 років, кількість хворих на артеріальну гіпертензію не перевищує поширеність цього захворювання в популяції в цілому.

18 хворих $(20,69 \%)$ мали інші супутні захворювання. Їх спектр був надзвичайно широкий i охоплював патологію практично всіх органів i систем. Основні з них:

- Хвороби серця і судин (крім гіпертонічної хвороби) - 4 хворих (4,6\%);

- Захворювання та синдроми ураження нервової системи - 5 хворих $(5,75 \%)$;

- Хвороби органів травлення - 1 хворий $(1,15 \%)$;

- Ендокринні захворювання - 6 хворих (6,9\%) (в т.ч. цукровий діабет - 4 (4,6\%));

- ревматоїдний артрит - 1 хворий $(1,15 \%)$;

- залізодефіцитна анемія - 1 хворий $(1,15 \%)$.

Найбільш широко були представлені такі поширені захворювання, як ішемічна хвороба серця, виразкова хвороба шлунка, цукровий діабет.

Різні захворювання і синдроми ураження не- рвової системи в анамнезі відзначені у 5 хворих. Найчастіше це були дисциркуляторна енцефалопатія, судомний синдром, САК в анамнезі. «Сімейні» аневризми виявлено у 2 хворих: в 1 випадку аневризма була у одного з батьків, в 1 випадку - у рідної сестри. У 1 хворої крововилив з аневризми розвинувся на тлі вагітності в строки 17 тижнів. СAK:

Виявлені наступні фрактори ризику розвитку

- наявність в сімейному анамнезі САК у родичів - у 2 (2,3\%) пацієнтів;

- наявність в анамнезі шкідливих звичок: паління - у 22 (50\%) чоловіків і 7 (18,28\%) жінок; зловживання алкоголем - у 5 (11,36\%) чоловіків і 1 (2,33\%) жінки;

- наявність в анамнезі гіпертонічної хвороби - у 17 (38,64\%) чоловіків і $26(60,47 \%)$ жінок

- атеросклероз та гіперхолестеринемія - у 10 жінок та 14 чоловіків (23,26 і 31,82\% відповідно) (рис. 5).

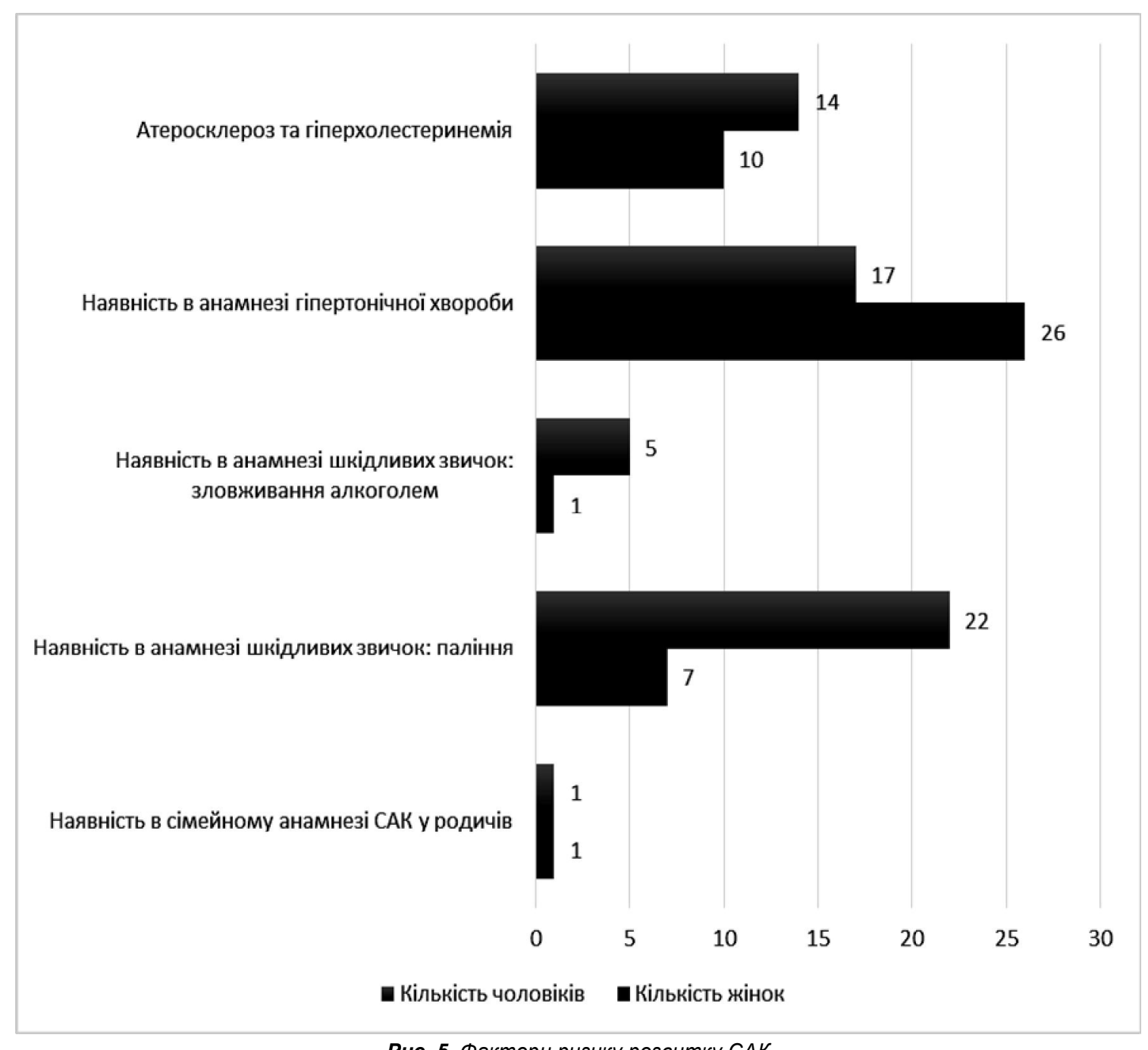

Puc. 5. Фактори ризику розвитку САК 


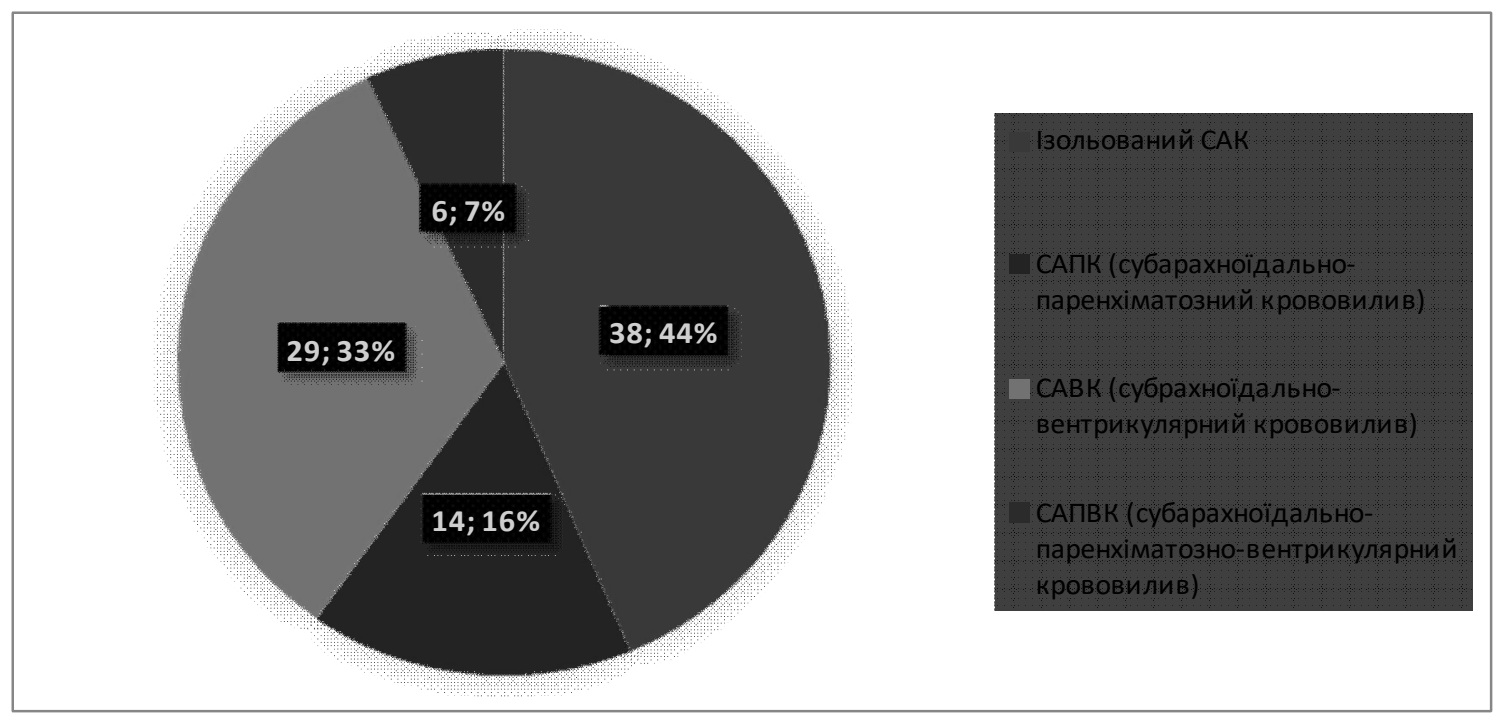

Puc. 6. Типи субарахноїдального крововиливу

Розподіл пацієнтів за типом субарахноїдального крововиливу відбувався наступним чином: 38 пацієнтів мали ізолований тип САК (43,68\%), 29 пацієнтів мали субрахноїдальновентрикулярний крововилив (33,33\%), у 14 пацієнтів діагностовано субарахноїдальнопаренхіматозний крововилив $(16,09 \%)$, та у $6-$ субарахноїдально-паренхіматозновентрикулярний крововилив (6,90\%). Таким чином, переважає ізольований тип САК в даній вибірці пацієнтів (рис. 6).

Були діагностовані наступні ускладнення у обстежених пацієнтів із САК (табл. 5). Характер неврологічних змін та ускладнень у обстежених пацієнтів із САК

\begin{tabular}{|c|c|c|}
\hline Ускладнення & Кількість пацієнтів & Відсоток від загальної кількості \\
\hline Головний біль & 50 & $57,47 \%$ \\
\hline Нудота / рвота & 24 & $27,59 \%$ \\
\hline Реактивні больові симптоми & 40 & $45,98 \%$ \\
\hline Загальна гіперестезія & 41 & $47,13 \%$ \\
\hline М'язові тонічні симптоми & 48 & $55,17 \%$ \\
\hline Судомний напад & 13 & $14,94 \%$ \\
\hline Короткочасна втрата свідомості & 24 & $27,59 \%$ \\
\hline Руховий дефіцит & 16 & $18,39 \%$ \\
\hline Мовні порушення & 4 & $4,6 \%$ \\
\hline Вазоспазм & 54 & $62,07 \%$ \\
\hline Відстрочена (вторинна) ішемія & 27 & $31,03 \%$ \\
\hline Гідроцефалія & 15 & $17,24 \%$ \\
\hline Набряк головного мозку & 7 & $8,05 \%$ \\
\hline Повторний крововилив & 3 & $3,45 \%$ \\
\hline
\end{tabular}

Частіше всього виявляли наступні симптоми, ранні та пізні ускладнення: головний біль у 50 пацієнтів (57,47\%), м'язові тонічні симптоми у 48 чоловік $(55,17 \%)$, у 51 хворого виник вазоспазм $(62,07 \%)$, загальна гіперестезія та реактивні больові симптоми у 41 та 40 хворих відповідно $(47,13$ та 45,98\%). Майже четверта частина хворих скаржилася на нудоту і рвоту $(27,59 \%)$, короткочасну втрату свідомості $(27,59 \%)$, а також майше в половині випадків була діагностована відстрочена (вторинна) ішемія (31,03\%). Гідроцефалію мали 15 осіб (17,24\%), руховий дефіцит - 16 (18,39\%), а судомні напади відбувалися у 13 пацієнтів (14,94\%). Повторний крововилив був діагностований лише у 3 хворих $(3,45 \%)$. Четверо хворих мали серед ускладнень мовні порушення $(4,6 \%)$, а набряк головного мозку розвинувся у 7 чоловік $(8,05 \%)$.
Розподіл хворих за вираженістю обсягу крововиливу і наявністю крові у шлуночках головного мозку згідно модифікованої шкали Fisher представлено на рис. 7.

У 34 пацієнтів було виявлене мінімальне або тонке САК без ознак ВШК в будь-якому із бічних шлуночків $(39,08 \%)$, у 22 чоловік в субарахноїдальному просторі діагностовано мінімальне або тонке САК з ознаками ВШК в обох бічних шлуночках (25,29\%), що відповідає 1 та 2 класу вираженості крововиливу, відповідно. Ще у 17 хворих було знайдено товстий шар субарахноїдального крововиливу без ознак ВШК в будьякому з бічних шлуночків, і у 14 пацієнтів був найбільш масивний крововилив - товстий шар САК з ознаками ВШК в обох бічних шлуночках $(16,09 \%)$, що відповідає 3 та 4 класу за модифрікованою шкалою Fisher.

\section{Том 18, Випуск 4 (64)}




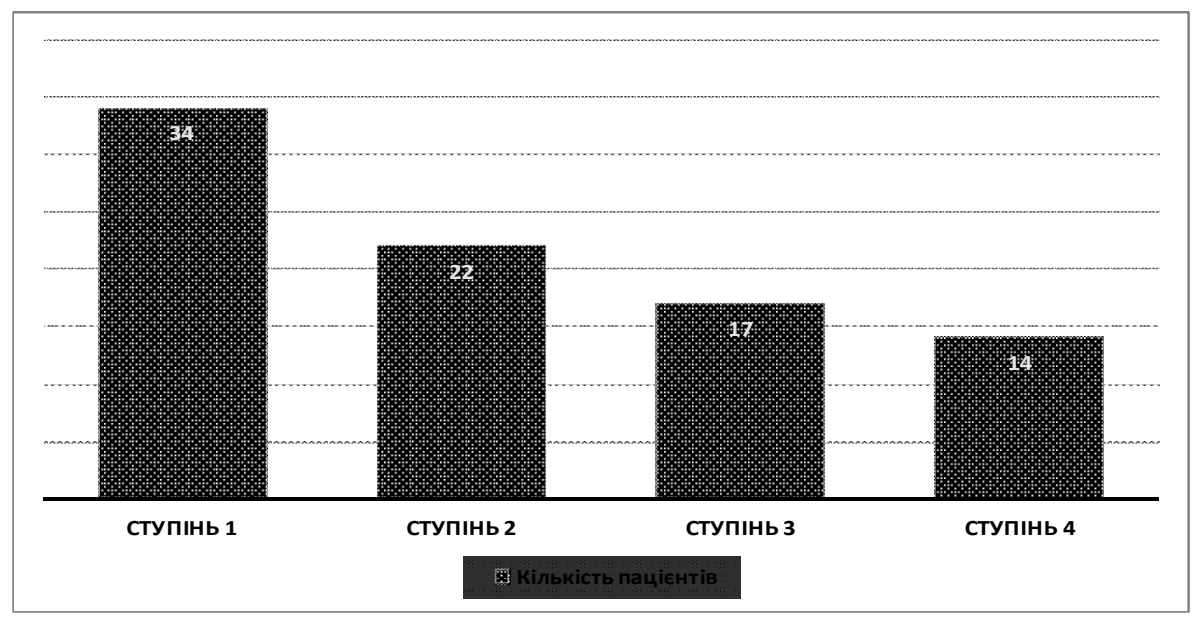

Puc. 7. Розподіл хворих за вираженістю обсягу крововиливу і наявністю крові у шлуночках головного мозку згідно модифрікованої шкали Fisher

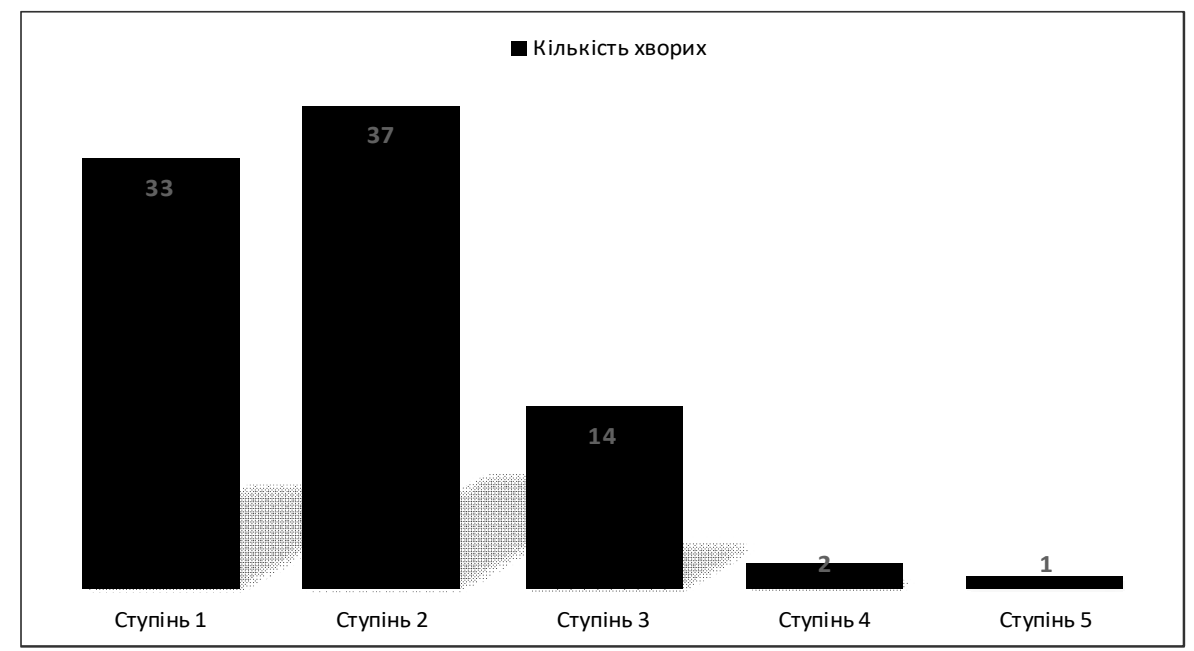

Рис. 8. Розподіл хворих за ступенем тяжкості відповідно

до класифрікації Всесвітньої організації нейрохірургів для оцінки тяжкості CAK (WFNS)

Розподіл хворих за ступенем тяжкості відповідно до класифікації Всесвітньої організації нейрохірургів для оцінки тяжкості САК наведено на рис. 8.

Більшість хворих даної вибірки мали найлегший ступінь тяжкості САК згідно класифрікації Всесвітньої організації нейрохірургів - 33 пацієнта (37,93\%), що відповідає 15 балам за шкалою ком Глазго та відсутності рухового та мовного десріциту. Друга ступінь тяжкості діагностована у 37 чоловік (42,53\%), це 13-14 балів за шкалою ком Глазго та відсутність рухового і мовного дефіциту. Наступна невелика когорта пацієнтів відносилася до 3 ступеню тяжкості - 14 хворих $(16,09 \%)$, вони мали 13-14 балів за шкалою ком Глазго та певного ступеню вираженості руховий і / або мовний дефіцит. Дві людини були віднесені до 4 ступеню тяжкості (2,30\%) із 7-12 балами за шкалою ком Глазго та наявністю / відсутністю рухового і / або мовного дефріциту. Один хворий $(1,15 \%)$ належав до категорії крайного 5 ступеню тяжкості із 3-6 балами за шкалою ком Глазго та наявністю / відсутністю рухового і / або мовного десріциту.

Розподіл хворих за ступенем тяжкості згідно шкали Hunt \& Hess представлено на рис. 9.

Таким чином, згідно класифрікації Hunt \& Hess в даній когорті 34 пацієнта $(39,08 \%)$ не мали зовсім симптомів або симптоми були мінімальні: головний біль та ригідність потиличних м'язів, що відповідає 1 ступеню тяжкості. Найбільша кількість пацієнтів відносилася до 2 ступеню тяжкості - 36 чоловік $(41,38 \%)$, із симптомами у вигляді головного болю, ригідністі потиличних м'язів, відсутністі неврологічного дефіциту (крім паралічу черепних нервів). Сонливість, оглушення або легкий вогнищевий десріцит та 3 ступінь тяжкості діагностовано у 14 хворих (16,09\%). Тяжкий стан у вигляді ступору, помірного або важкого геміпарезу, ранньою децеребраційною ригідністю, вегетативними розладами виявлено у 3 хворих $(3,45 \%)$. Вкрай важкий стан і 5 ступінь тяжкості із глибокою комою, децеребраційною ригідністю та термінальним станом не виявлено у жодного пацієнта. 


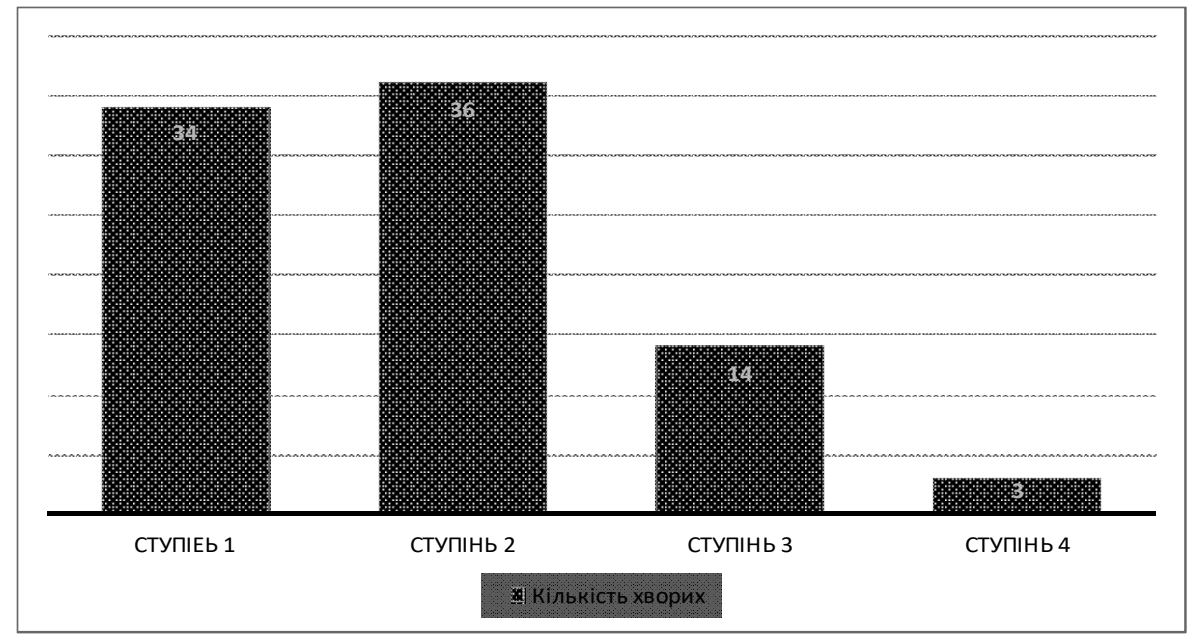

Puc. 9. Розподіл хворих за ступенем тяжкості згідно шкали Hunt \& Hess

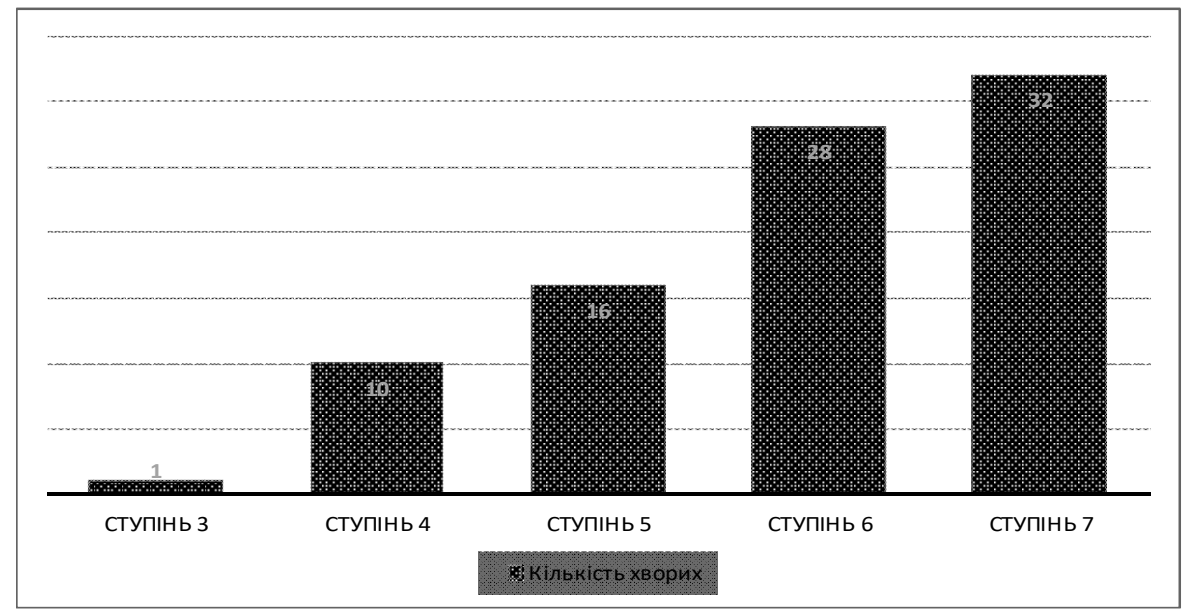

Puc. 10. Розподіл хворих за шкалою результатів GOSE (Glasgow Outcome Scale Extended)

Розподіл хворих за шкалою результатів GOSE (Glasgow Outcome Scale Extended) наведено на рис. 10.

Згідно шкали результатів GOSE (Glasgow Outcome Scale Extended), одна людина (1,15\%) із 3 ступенем має нейром'язову неспроможність: пацієнт у свідомості, однак важка неврологічна симптоматика змушує продовжувати лікування у відділенні реанімації. Далі 10 хворих $(11,49 \%)$ із 4 ступенем тяжкості мають важку неспроможність: є грубий неврологічний дефект, через який пацієнтам необхідний сторонній догляд. Помірна несамостійність: психічний статус в межах норми, при цьому пацієнти не в змозі виконувати ряд необхідних дій та потребують амбулаторного спостереження, діагностовано у 16 хворих $(18,39 \%)$, що відповідає 5 ступеню. Легка несамостійність: психічний статус в межах норми, хворі самі себе обслуговують, самі рухаються або зі сторонньою підтримкою. проте потребують спеціального працевлаштування, виявлено у 28 чоловік $(32,18 \%)$ із 6 ступенем тяжкості. Гарне відновлення: пацієнти поступово повертаються до колишнього життя, $€$ незначні невроло- гічні порушення, пересуваються самостійно, демонструє найчисельніша когорта хворих - 32 людини $(36,78 \%)$ у групі 7 ступеню тяжкості.

Причому, слід зазначити, що реєстрація бального показнику згідно GOSE більше 7, статистично частіше спостерігалась у групі із відсутністю МА або артеріо-венозної мальформації за даними обстеження у порівнянні із хворими з чіткою детекцією наявності аневризматичної васкулярної патології ( $x^{2}=14,57$ при $\left.p<0,001\right)$.

Розподіл пацієнтів згідно узагальнюючої класифікаційної шкали для оцінки прогнозу результату CAK (C.S. Ogilvy et B.S. Carter) (pиc. 11).

Відсоток вірогідності прогнозу САК $78-80 \%$ успішного результату згідно узагальнюючої класифікаційної шкали для оцінки прогнозу результату CAK (C.S. Ogilvy et B.S. Carter) мали 76 хворих із балами від 0 до 2 (87,36\%), тобто найбільша кількість хворих. Три бали та 65-67\%, менш успішний результат продемонстрували 10 хворих $(11,49 \%)$. У одного хворого $(1,15 \%)$ нараховано $25 \%$, несприятливий результат та сумарні 4 бали. 


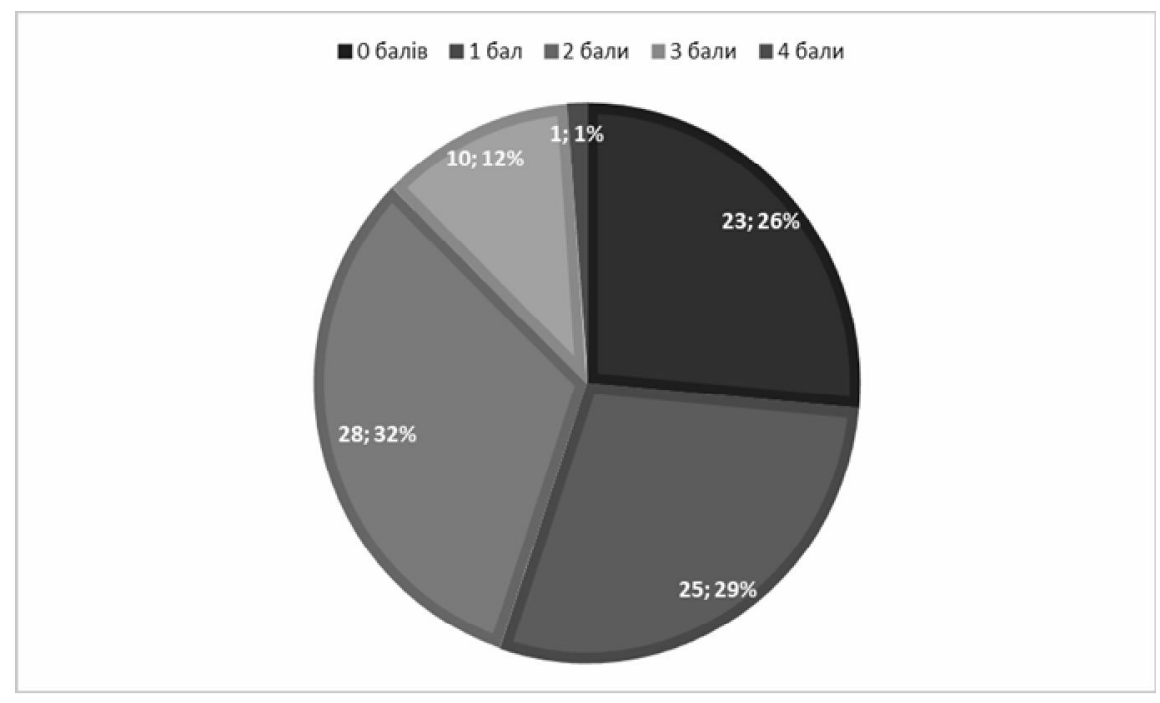

Pис. 11. Розподіл пацієнтів зәідно узагальнюючої класифікаційної шкали для оцінки прогнозу результату CAK (C.S. Ogilvy et B.S. Carter)

Оперативне лікування було виконано у 40 хворих (46\%), консервативна терапія, відповідно, застосовувалася для 47 хворих (54\%). Середня тривалість стаціонарного лікування склала 17,64 ліжко-днів.

\section{Обговорення отриманих результатів}

У ряді досліджень вказано, що фактори зовнішнього середовища можуть сприяти розвитку артеріальних аневризм [19]. Ця теза підтверджується наявністю внутрішньочерепних аневризм у дітей, i, хоча середній вік хворих із аневризматичним САК становить 50 років, частота даного захворювання збільшується з віком [26].

Серед різних факторів навколишнього середовища, які можуть привести до розвитку артеріальних аневризм і подальшого САК, провідним $€$ паління. За оцінками дослідників, ризик аневризматичного САК у курців приблизно в 3-10 разів вище, ніж у людей, що не палять. Крім того, ризик зростає зі збільшенням кількості цигарок за один день [27]. До кінця не зрозуміло, яким чином паління призводить до утворення аневризми, проте існує кілька теорій. Паління знижує активність А1-антитрипсину, основного інгібітору протеолітичних ферментів, таких як еластаза, і дисбаланс між протеазами та їх інгібіторів у нікотинозалежних людей може привести до деструкції основної речовини сполучної тканини, в тому числі еластичних волокон в стінці церебральних артерій. На підтримку цієї гіпотези виступає фракт, що у пацієнтів з генетично обумовленою недостатністю А1-антитрипсину підвищений ризик розвитку артеріальних аневризм [28].

Артеріальна гіпертензія $є$ найбільш вивченим фактором ризику для розвитку і розриву внутрішньочерепних аневризм. Цілий ряд досліджень показав, що гіпертонічна хвороба сприяє розвитку артеріальної аневризми і в майбутньому САК. При проведенні патологоанатомічного розтину у хворих із артеріальними аневризмами часто виявляють гіпертрофрію лівого шлуночка серця, без встановленого при житті підвищення артеріального тиску [29].

Захворюваність артеріальними аневризмами і викликаними ними САК, на відміну від інших типів інсульту, вище серед жінок, ніж серед чоловіків до п'ятдесяти років, що свідчить про роль гормональних чинників. Однак використання малих доз оральних контрацептивів під час пременопаузи не збільшує, а навіть може знижувати ризик розвитку САК. Ризик аневризматичного САК нижче серед жінок в постменопаузі, які отримують гормон-замісну терапію, ніж у жінок в постменопаузі, які не отримували таке лікування [30].

Дані про вплив на розвиток артеріальних аневризм надмірного вживання алкоголю і гіперхолестеринемнії суперечливі [31].

Дослідниками [32] було становлено негативний вплив стенозів екстракраніальних відділів магістральних артерій голови (більше $75 \%$ на боці розриву артеріальної аневризми) і анатомічних особливостей будови Віллізієвого кола (трифуркація на боці, протилежному локалізації аневризми, яка розірвалася) на функціональні виходи при субарахноїдальних крововиливах. Автори резюмують, що клінічні, структурні та гемодинамічні порушення, які визначають перебіг САК, дають можливість розробити прогностичні критерії несприятливого функціонального виходу захворювання: гноблення свідомості до сопору і коми більше 3 діб, важкість стану при надходженні за НH IV - V ступенів, наявність грубого фокального неврологічного дефіциту, поширеність крові, яка вилилася - +3 - +4 (за Sano), масивність крововиливу III, IV ступенів (за Fisher), виразність вентрикулярного компоненту більше 6 балів (за Graeb), наявність дислокаційного синдрому і набряку мозку II - III ступенів, формування томографічних ознак вторинної ішемії, наявність вираженого, критичного (за доплерографією) і вираженого та розповсюдженого (за ангіографією) ангіоспазму. Відсутність да- 
них ознак дозволяє прогнозувати сприятливий перебіг захворювання.

\section{Висновки}

1. Виявлені наступні фрактори ризику розвитку САК: наявність в сімейному анамнезі САК у родичів; наявність в анамнезі шкідливих звичок: паління; зловживання алкоголем; наявність в анамнезі гіпертонічної хвороби, атеросклерозу та гіперхолестеринемії.

2. Найбільш широко були представлені такі супутні захворювання, як ішемічна хвороба серця, виразкова хвороба шлунка, цукровий діабет.

3. Хворі в гострому періоді аневризматичного САК представляють гетерогенну групу, як за клінічним станом, так і за показниками інструментальних досліджень.

4. Важкість стану залежить від поширеності крововиливу і подальшої динаміки основних патологічних процесів в цереброваскулярній системі, в першу чергу, набряку мозку і ангіоспазму.

5. Хворі з різним поєднанням і виразністю патологічних процесів із САК, можуть бути віднесені в одну групу за класифікацією хворих за шкалою $\mathrm{H}-\mathrm{H}$ або WFNS.

6. Оцінка цих процесів та їх розвитку в часі має вирішальне значення при визначенні тактики ведення хворого.

Перспективами подальших досліджень $\epsilon$ аналіз взаємозв'язку параметрів клінічних шкал з рівнем потенційного прогностичного маркеру при нетравматичному генезі САК.

\section{References}

1. Myshchenko TS. Epydemyologyya tserebrovaskulyarnykh zabolevanyy y organyzatsyya pomoshchy bolnym s mozgovym ynsultom v Ukrayne [Epidemiology of cerebrovascular diseases and organization of care for patients with cerebral stroke in Ukraine]. Ukrayinskyy visnyk psykhonevrologiyi. 2017; 25(1): 22-4. [Russian]

2. Pedachenko YeG, Polishchuk MYe, Guk AP, Aksonov VV. I $\begin{array}{llll}\text { Mizhnarodni Osvitni kursy } & \text { Vsesvitnoyi Federatsiyi } \\ \text { Neyrokhirurgichnykh Tovarystv v Ukrayini [I International }\end{array}$ Educational Courses of the World Federation of Neurosurgical Associations in Ukraine]. Ukrayinskyy neyrokhirurgichnyy zhurnal. 2011; 3: 76-7. [Ukrainian]

3. Tsymeyko OA, Novykov RR. Lechenye subarakhnoydalnoparenkhymatoznogo krovoyzlyyanyya, voznykshego vsledstvye razryva anevryzmy sredney mozgovoy arteryy [Treatment of razryva anevryzmy sredney mozgovoy arteryy [Treatment of subarachnoid-parenchymal hemorrhage resulting from rupture of the
aneurysm of the middle cerebral artery]. Ukrayinskyy neyrokhirurgichnyy zhurnal. 2014; 2: 68-71. [Russian]

4. van Gijn J, Kerr RS, Rinkel GJ. Subarachnoid haemorrhage. Lancet. 2007; 369: 306-18.

5. Sandvei MS, Mathiesen EB, Vatten LJ, et al.. Incidence and mortality of aneurysmal subarachnoid hemorrhage in two Norwegian cohorts, 1984-2007. Neurology. 2011; 77: 1833-9.

6. Fischer $T$, Johnsen SP, Pedersen $L$, et al. Seasonal variation in hospitalization and case fatality of subarachnoid hemorrhage-a nationwide Danish study on 9,367 patients. Neuroepidemiology. 2005; 24 : 32-7.

7. Koffijberg $H$, Buskens $E$, Granath $F$, et al. Subarachnoid haemorrhage in Sweden 1987-2002: regional incidence and case fatality rates. J Neurol Neurosurg Psychiatry. 2008; 79: 294-9.

8. The ACROSS Group. Epidemiology of aneurysmal subarachnoid hemorrhage in Australia and New Zealand: incidence and case fatality from the Australasian Cooperative Research on fatality from the Australasian Cooperative Research
Subarachnoid Hemorrhage Study. Stroke. 2000; 31: 1843-50.

9. Rose MJ. Aneurysmal subarachnoid hemorrhage: an update on the medical complications and treatments strategies seen in these patients. Curr Opin Anaesthesiol. 2011; 24: 500-7.

Том 18, Випуск 4 (64)
10. Bederson JB, Connolly ES Jr, Batjer $\mathrm{HH}$, et al. American Heart Association: Guidelines for the management of aneurysmal subarachnoid hemorrhage: a statement for healthcare professionals from a special writing group of the Stroke Council, American Heart Association. Stroke. 2009; 40: 994-1025.

11. Priebe HJ. Aneurysmal subarachnoid haemorrhage and the anaesthetist. Br J Anaesth. 2007; 99: 102-18.

12. Rinkel GJ, Djibuti M, Algra A, et al.. Prevalence and risk of rupture of intracranial aneurysms: a systematic review. Stroke. 1998; 29: 2516.

13. Feigin VL, Rinkel GJ, Lawes $C M$, et al.. Risk factors for subarachnoid hemorrhage: an updated systematic review of epidemiological studies. Stroke. 2005; 36: 2773-80.

14. Bor AS, Rinkel GJ, Adami J, et al.. Risk of subarachnoid haemorrhage according to number of affected relatives: a population based case-control study. Brain. 2008; 131(Pt 10): 2662-5.

15. Eden SV, Meurer WJ, Sánchez BN, et al.. Gender and ethnic differences in subarachnoid hemorrhage. Neurology. 2008; 71: 7315.

16. Zheng $\mathrm{Y}$, Zhou B, Wang $\mathrm{X}$, Chen $\mathrm{H}$, Fang $\mathrm{X}$, Jiang $\mathrm{P}$, et al. Size, Aspect Ratio and Anatomic Location of Ruptured Intracranial Aneurysms: Consecutive Series of 415 Patients from a Prospective Multicenter, Observational Study. Cell Transplant. 2018 Dec 4: Multicenter, Obser

17. Ogilvy CS, Carter BS. A proposed comprehensive grading system to predict outcome for surgical management of intracranial aneurysms. Neurosurgery. 1998 May; 42(5): 959-68; discussion 968-70.

18. Hunt WE, Hess RM. Surgical risk as related to the time of intervention in the repair of intracranial aneurysms. J Neurosurg. 1968; 28: 14-20.

19. Muehlschlegel S. Subarachnoid Hemorrhage. Continuum (Minneap Minn). 2018 Dec; 24(6): 1623-57.

20. Shmyrev VY, Arkhypov SL, Kuznetsov SE, Ternovoy SY Neyrovyzualyzatsyonnaya dyagnostyka y osobennosty lechenyya gemorragycheskogo ynsulta [Neuroimaging diagnosis and treatment of hemorrhagic stroke]. Zhurn nevrol y psykh ym SN Korsakova. 2001; 101(1): 27-31. [Russian]

21. Catapano JS, Zabramski JM, Baranoski JF, Brigeman S, Morgan CD, Hendricks BK, et al. The Prognostic Significance of a Cast Fourth Ventricle in Ruptured Aneurysm Patients With Intraventricular Hemorrhage in the Barrow Ruptured Aneurysm Trial (BRAT). Hemorrhage in the Barrow Ruptured Aneurysm Trial
Neurosurgery. 2018 Nov 23. doi: 10.1093 /neuros/nyy493

22. Aggarwal V, Sharma A, Sinha VD. Role of Diffusion-weighted Imaging in Detecting Early Ischemic Brain Injury Following Aneurysmal Subarachnoid Hemorrhage. Asian J Neurosurg. 2018 Oct-Dec; 13(4): 1074-7. doi: 10.4103/ains.AJNS 7317

23. Basile-Filho A, Lago AF, Menegueti MG, Nicolini EA, Nunes RS, Lima SL, et al. The use of SAPS 3, SOFA, and Glasgow Coma Scale to predict mortality in patients with subarachnoid hemorrhage: A retrospective cohort study. Medicine (Baltimore). 2018 Oct; 97(41): e12769. doi: 10.1097/MD.0000000000012769

24. Lebedev VV, Krylov VV, Kholodov SA, Shelkovskyy VN. Khyrurgyya anevryzm golovnogo mozga $v$ ostrom peryode krovoyzlyyanyya
[Brain aneurysm surgery in acute hemorrhage]. M: Medytsyna; [Brain aneurysm surgery
1996. 256 p. [Russian]

25. Wong H, Hodgson L, Banfield J, Shankar JJS. Digital Subtraction Angiography for CT Angiogram Negative Haemorrhages. Can $J$ Neurol Sci. 2018 Sep; 45(5): 522-6. doi: 10.1017/cjn.2018.75

26. Zozulya YuP, Mishchenko TS. Problemy sudynno-tserebralnoyi patologiyi ta shlyakhy yikh vyrishennya [Problems of vascularcerebral pathology and ways of their solution]. Zhurn NAMN Ukrayiny. 2011; 17(1): 19-25. [Ukrainian]

27. Steiner $\mathrm{T}$, Juvela $\mathrm{S}$, Unterberg A. European Stroke Organization Guidelines for the Management of Intracranial Aneurysms and Subarachnoid Haemorrhage. Cerebrovasc Dis. 2013; 35: 93-112.

28. Kolias AG, Sen J, Bell A. Pathogenesis of cerebral vasospasm following aneurysmal subarachnoid hemorrhage: putative mechanisms and novel approaches. J Neuroscience Res. 2009; 87: $1-11$.

29. Pluta R. Dysfunction of nitric oxide syntases as a cause and therapeutic target in delayed cerebral vasospasm after SAH. Cerebral Vasospasm. New Strategies in Research and Treatment. Ed by T Kiris, JH Zhang. Wien, New York: Springer Verlag; 2008. p. Ed by $T$ Ki
$139-47$

30. Ayer RE, Zhang JH. Oxidative stress in subarachnoid haemorrhage: significance in acute brain injury and vasospasm. Acta Neurochir (Wien). 2008; 104(Suppl): 33-41.

31. Dyzregulyatsyonnaya patologyya nervnoy systemy [Disregulation pathology of the nervous system]. Ed by EY Gusev, GN Kryzhanovskyy. M: MYA; 2009. 512 p. [Russian]

32. Dzyak LA, Golyk VA. Sovremennye metody konservatyvnogo lechenyya anevryzmatycheskykh subarakhnoydalnykh krovoyzlyyanyy [Modern methods of conservative treatment of aneurysmal subarachnoid hemorrhage]. Mezhdunarodnyy medytsynskyy zhurnal. 2002; 8(3): 23-8. [Russian] 


\begin{abstract}
Реферат
ОСОБЕННОСТИ КЛИНИЧЕСКОГО ТЕЧЕНИЯ СУБАРАХНОИДАЛЬНОГО КРОВОИЗЛИЯНИЯ НЕТРАВМАТИЧЕСКОГО ГЕНЕЗА В ОСТРОМ ПЕРИОДЕ ЗАБОЛЕВАНИЯ

Полковникова К. Ю.

Ключевые слова: субарахноидальное кровоизлияние, Шкала Всемирной федерации нейрохирургов (WFNS), шкала ХантаХесcа, шкала Fisher, шкала C.S. Ogilvy et B.S. Carter, шкала GOSE.

Цель исследования: изучить клинико-статистическую характеристику, особенности течения заболевания, динамику результатов неврологических шкал и структуру осложнений у стационарных больных, госпитализированных по поводу субарахноидального кровоизлияния нетравматической этиологии. Обследовано 87 пациентов с субарахноидальным кровоизлиянием, из них 38 (43,68\%) - с изолированным, 14 (16,09\%) - с субарахноидально-паренхиматозным, 29 (33,33\%) - с субарахноидальножелудочковым, 6 (6,9 \%) - с субарахноидально-паренхиматозно-желудочковым кровоизлиянием, общее количество смешанных кровоизлияний составляла $56,32 \%$. В рутинное клиническое обследование были также дополнительно включены шкала C.S. Ogilvy et B.S. Carter и шкала GOSE. Большинство больных данной выборки имели легкую степень тяжести субарахноидального кровоизлияния согласно классификации Всемирной федерации нейрохирургов - 33 пациента (37,93\%), что соответствует 15 баллам по шкале ком Глазго и отсутствию двигательного и речевого дефицита. Вторая степень тяжести диагностирована у 37 человек (42,53\%), это 13-14 баллов по шкале ком Глазго и отсутствие двигательного и речевого дефицита. Следующая небольшая когорта пациентов относилась к 3 степени тяжести - 14 больных (16,09\%), они имели 13-14 баллов по шкале ком Глазго и определенной степени выраженности двигательный и / или речевого дефицит. Два человека были отнесены к 4 степени тяжести (2,30\%) с 7-12 баллами по шкале ком Глазго и наличием / отсутствием двигательного и / или речевого дефицита. Один больной (1,15\%) принадлежал к категории крайней 5 степени тяжести с 3-6 баллами по шкале ком Глазго и наличием / отсутствием двигательного и / или речевого дефицита. Процент вероятности прогноза субарахноидального кровоизлияния 78-80\% успешного результата согласно обобщающей классификационной шкалы для оценки прогноза результата субарахноидального кровоизлияния (C.S. Ogilvy et B.S. Carter) имели 76 больных с баллами от 0 до 2 (87,36\%). Три балла и 65-67\% на менее успешный результат продемонстрировали 10 больных $(11,49 \%)$. У одного больного (1,15\%) получено $25 \%$ риска неблагоприятного исхода и суммарные 4 балла. Выявлены следующие фракторы риска развития субарахноидального кровоизлияния: наличие в семейном анамнезе данного заболевания у родственников; наличие в анамнезе вредных привычек: курение, злоупотребление алкоголем; наличие в анамнезе гипертонической болезни, атеросклероза и гиперхолестеринемии. Из сопутствующих болезней наиболее широко были представлены такие заболевания, как ишемическая болезнь сердца, язвенная болезнь желудка, сахарный диабет.
\end{abstract}

\title{
Summary
}

CHARACTERISTICS OF THE CLINICAL COURSE OF NON-TRAUMATIC SUBARACHNOID HAEMORRHAGE IN ACUTE PHASE OF THE DISEASE

Polkovnikova K. Yu.

Key words: subarachnoid haemorrhage, Scale of the World Federation of Neurosurgeons (WFNS), Hanth-Hess scale, Fisher scale, C.S. Ogilvy et B.S. Carter scale, GOSE scale.

The purpose of the study was to investigate the clinical and statistical characteristics of the course of the disease, to assess the dynamics of the results according to the neurological scales, and to reveal the structure of complications in patients hospitalized for subarachnoid haemorrhage of non-traumatic aetiology. Materials and methods. 87 patients with subarachnoid haemorrhage were examined, 38 of them $(43.68 \%)$ had isolated subarachnoid haemorrhage, $14(16.09 \%)$ had subarachnoid parenchymal, $29(33.33 \%)$ had subarachnoid ventricular, and $6(6.9 \%)$ had subarachnoid-parenchymal ventricular haemorrhage. The total number of mixed haemorrhages made up $56.32 \%$. In the routine clinical examination the C.S. Ogilvy et B.S. Carter Scale and the GOSE Scale were additionally included. Results. The majority of patients, 33 patients $(37.93 \%)$, had subarachnoid haemorrhage of a mild severity according to the classification of the World Federation of Neurosurgeons that corresponded to 15 scores by the Glasgow Coma Scale and the absence of motor and speech deficit.

The second degree of the severity was diagnosed in 37 people $(42.53 \%)$ that corresponded to $13-14$ scores according to the Glasgow Coma Scale and no motor and speech deficit. The next small group of patients, 14 patients $(16.09 \%)$, had the 3 degree of the severity, i.e. 13 - 14 scores according to the Glasgow Coma Scale and a certain degree of motor and / or speech deficiency. Two individuals $(2.30 \%)$ were assessed as having the 4 degree that was 7-12 scores by the Glasgow Coma Scale and the presence / absence of motor and / or speech deficit. One patient (1.15\%) belonged to the 5 category, whose condition was assessed as extremely severe, 3-6 scores by the Glasgow Coma Scale and the presence / absence of motor and / or speech deficit. 76 patients with the subarachnoid haemorrhage assessed as having from 0 to 2 scores had $78-80 \%$ likelihood of successful outcomes according to the generalizing classification scale for the assessment of the subarachnoid haemorrhage result forecast (CSU. Ogilvy ET B.S. Carter). 10 patients $(11.49 \%)$ with 3 scores demonstrated a less successful outcome. One patient $(1.15 \%)$ was found to have 
$25 \%$ risk of adverse outcome and a total of 4 scores. Conclusion. The following risk factors for the development of subarachnoid haemorrhage were identified: the presence in of subarachnoid haemorrhage among relatives in the family history; history of bad habits including smoking, alcohol abuse; history of hypertension, atherosclerosis and hypercholesterolemia; concomitant diseases, including coronary heart disease, peptic ulcer and diabetes mellitus.

DOI:10.31718/2077-1096.18.4.59

УДК 616-005.4-06:612.172.2:616.379-008.64

Строна В.І., Горб Ю.Г., Комір І.Р.

ВАРІАБЕЛЬНІСТЬ РИТМУ СЕРЦЯ У ХВОРИХ СТАБІЛЬНОЮ
ІШЕМІЧНОЮ ХВОРОБОЮ СЕРЦЯ 3 ЦУКРОВИМ ДІАБЕТОМ 2 ТИПУ

ДУ «Національний інститут терапії ім. Л.Т. Малої НАМН України», Харків

Мета дослідження - оцінити часові та спектральні показники варіабельності серцевого ритму у пацієнтів на стабільну фоорму ішемічної хвороби серия і иукрового діабету 2 типу за даними добового моніторування електрокардіографрії за Холтером (ХМ ЕКГ). Матеріал і методи. Обстежено 61

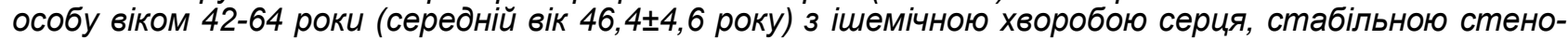
кардією напруги II-III функціональних класів. У тому числі 34 хворі (1-а група) мали цукровий діабет 2 типу. 2-а група - 27 осіб без порушень вуглеводного обміну. Всім хворим проводилося ХМ ЕКГ з подальшим аналізом показників варіабельності серцевого ритму. Контрольну групу склали 15 осіб з гіпертонічною хворобою II cm без ішемічної хвороби серия та иукрового діабету. Результати та обговорення. Встановлено, що в обох групах хворих на ішемічну хворобу серия, незалежно від наявності цукрового діабету, відзначалося зменшення циркадного індексу в порівнянні з хворими з гіпертонічною хворобою, що, ймовірно, свідчить про стан вегетативної "денерваиії" серия, розвитку ригідності добового циркадного профрілю частоти серцевих скорочень. При збільшенні рівня глікозильованого гемоглобіну у пацієнтів 1-ї групи відзначено зниження часових показників варіабельності ритму серия і циркадного індексу. Кількість надшлуночкових і шлуночкових екстрасистол за добу було статистично достовірно більше у хворих 1-ї групи ( $p<0,001, p<0,002$ відповідно) в порівнянні з групою хворих на ішемічну хворобу серця без иукрового діабету. У пацієнтів з ішемічною хворобою серия та цукровим діабетом за даними ХM ЕКГ спостерігалося зниження часових показників варіабельності серцевого ритму. У иій категорії хворих відмічалося загальне зниження варіабельності серцевого ритму - зменшення середньоквадратичного відхилення (SDNN), зміни спектральних характеристик (зменшення високочастотної складової спектра (HF), збільшення співвідношення LF/HF) з зміщенням балансу в бік симпатичного (низькочастотного) компонента. У пацієнтів зі стабільною формою ішемічної хвороби серця та иукровим діабетом 2 типу відзначається зменшення як часових, так і спектральних показників варіабельності серцевого ритму, що свідчить про зниження сумарної активності нейрогуморальних впливів на серцевий ритм. Вказані зміни пов'язані з підвищенням ектопічної активності міокарда.

Ключові слова: варіабельність ритму серця, ішемічна хвороба серця, цукровий діабет.

Дослідження було проведено в рамках науково-дослідної роботи «Вивчити вплив циркулюючих мікрорибонуклеінових кислот на метаболічні та імунозапальні чинники атерогенезу при поєднанні ішемічної хвороби серця з цукровим діабетом 2 типу», № держ. реєстрації $0117 \cup 003027$.

\section{Вступ}

Цукровий діабет (ЦД) 2-го типу є одним з головних незалежних фракторів ризику серцевосудинної патології, яка найчастіше визначає прогно3, в тому числі для життя, у цієї категорії хворих. Серцево-судинні ускладнення, зокрема аритмії, - причина смерті більше $60 \%$ таких пацієнтів [1]. На теперішній час виявлені суттєві взаємозв'язки між станом вегетативної нервової системи (BНC) і смертністю від серцево-судинних захворювань (СС3) [2]. Отримано експериментальні підтвердження тісного зв'язку між схильністю до летальних аритмій і ознаками підвищеної симпатичної і зниженої вагусної активності [3]. Це сприяло розвитку вчення про варіабельність ритму серця (ВРC), як про новий маркер вегетативної дисфункції у хворих з СС3 [4].

Згідно з рекомендаціями Комітету експертів
Європейського товариства кардіологів і Північноамериканського товариства кардіостимуляції та електрофрізіології, зниження ВРС розглядається як показник вікової інволюції ВНС, а також в якості предиктора життєво небезпечних шлуночкових аритмій, раптової смерті у постінфрарктних хворих, як фактор несприятливого прогнозу у пацієнтів з систолічною формою хронічної серцевої недостатності і як ранній маркер діабетичної нейропатії [5].

За даними холтерівського моніторування ЕКГ (ХМ ЕКГ) значення середньоквадратичного відхилення (SDNN) нижче 50 мсек або значення триангулярного індексу (HRV) нижче 15 од., визнаються прогностично несприятливими і свідчать про високий ризик виникнення небезпечних аритмій і раптової коронарної смерті [6]. При цьому вегетативно-рефрлекторні зміни передують гемодинамічним, метаболічним і енергетич-

$$
\text { Том 18, Випуск } 4 \text { (64) }
$$

